\title{
KOMPIUTERINIS REGOS SUTRIKIMO SINDROMAS - EPIDEMIOLOGIJA, DIAGNOSTIKA, GYDYMAS, PROFILAKTIKA
}

\author{
Dovilè Mišeikyte் ${ }^{1}$, Austẻja Judickaitė ${ }^{1}$, Skaistė Rita Kužmarskytė ${ }^{2}$ \\ ${ }^{1}$ Lietuvos sveikatos mokslu universiteto Medicinos akademijos Medicinos fakultetas, \\ ${ }^{2}$ Lietuvos sveikatos mokslu universiteto ligonine, Akiu ligu klinika
}

Raktažodžiai: kompiuterinis regos sutrikimo sindromas, sveikatos edukacija, darbo saugumo programos, akių simptomai.

\begin{abstract}
Santrauka
Kompiuterinis regos sutrikimo sindromas (KRSS) tai akių, judejjimo sistemos, psichoemocinès būklès bei miego sutrikimo simptomų kompleksas, atsirandantis dèl per ilgo sėdèjimo prie kompiuterio ekranų. Diagnozuojant ligą, svarbiausia išsiaiškinti galimus rizikos veiksnius ir klinikinius požymius, iš kurių dažniausi - akių sausumas ir pečių bei kaklo skausmas. Naudingi tyrimai: regos aštrumo ịvertinimas, akių judesių kokybès nustatymas, Širmerio testai, tam tikri klausimynai ir kt. Gydymas apima rizikos veiksnių vengimą: darbo kompiuteriu higienos korekcija, tinkamas poilsis, mankšta. Simptomams malšinti dažniausiai naudojami drèkinamieji akių geliai, raumenų įtampai malšinti skiriami masažai, elektrostimuliacinès procedūros. Svarbiausias kelias užkirsti KRSS yra profilaktika: tinkamas naudojimasis vaizdiniais prietaisais ir pertraukos darbo metu.
\end{abstract}

\section{Ivadas}

Dẻl fenomenalios technologijų pažangos kompiuteriai ir kiti elektroniniai vaizdiniai prietaisai tapo neatsiejama mūsų profesinio ir asmeninio gyvenimo dalimi [1]. Dèl COVID-19 pandemijos, kai visi imanomi darbai ir studijos vyksta nuotoliniu būdu, pailgèjo laikas, praleidžiamas prie ekranų. Ilgalaikis kompiuterių ekranų poveikis akims igavo ligos termina ir vadinamas kompiuteriniu regos sutrikimo sindromu (KRSS). Jis apima akiu ir ekstraokuliniu simptomu spektrą kompiuterių vartotojams, kurie naudoja kompiuterius ilgą laiką dieną ir naktị $[1,3]$. Žmones vargina ịvairūs regos sutrikimo simptomai: akių sausumas, sudirginimas, deginimas, nuovargis, neryškus matymas ir t.t. Kamuoja nugaros, raumenų skausmai bei miego sutrikimo sindromas, vedantis link psichologinių problemų. Sindromas gali išsivystyti dẻl kelių priežasčių: dèl akių (akių paviršiaus anomalijų ar spazmų) ir (arba) ergonominių priežasčiu [4]. Šis sindromas diagnozuojamas remiantis klinika ir anamnezès duomenimis, tik mažai daliai pacientų, o gydymas yra prevencinis - kompiuterinio darbo higiena bei švietimas, kadangi žinios apie KRSS yra prastos [3-5].

Tyrimo tikslas - atrinkti ir išanalizuoti literatūrą apie kompiuterinį regos sutrikimo sindromą, paplitimą, diagnostiką, gydymą ir profilaktiką.

\section{Tyrimo medžiaga ir metodai}

Teorinè informacija buvo renkama naudojant kompiuterines mokslinių darbų bazes: PubMed, Cohrane, ScienceDirect, UpToDate. Analizuoti 2015-2020 metais išspausdinti moksliniai straipsniai anglų kalba, atitinkantys tyrimo temą.

\section{Tyrimo rezultatai}

Epidemiologija. Kompiuterinis regėjimo sindromas yra didžiausias profesinis pavojus XXI amžiuje, o jo simptomai pasireiškia beveik 70 proc. visų kompiuterio vartotojų [5]. Visame pasaulyje KRSS yra viena iš pagrindinių visuomenès sveikatos problemų, dèl kurios sumažèja darbo našumas, padidejja klaidų lygis, mažeja pasitenkinimas darbu ir sutrinka regejjimas. Pasaulio duomenys rodo, kad beveik 60 milijonų žmonių serga KRSS, o kiekvienais metais registruojamas 1 milijonas naujų atvejų [5].

Etiologija - patogenezė ir klinika. Kompiuterio naudojimo trukmé, prastas apšvietimas, akinimas, ekrano ryškumas ir netinkama darbo vieta yra kompiuterinio regos sutrikimo sindromo aplinkos rizikos veiksniai [6]. Rizikos veiksniais laikomi ir regejjimo sutrikimai, tokie kaip: nekoreguotos refrakterinès ydos, senatvinè toliaregyste, akomodacijos, konvergencijos sutrikimai [7]. Regos sutrikimai pasireiškia miopija, sausumu, perštejjimu, ašarojimu, raudonų akių bei nuovargio simptomais [6]. KRSS yra kompleksas, apimantis ne tik akių pažeidimą, bet ir sutrikusị darbo efektyvumą, kadangi pacientus kamuoja 
nugaros ir kaklo-pečiu juostos skausmas, vargina emocijų kaita, miego sutrikimai ir dèl to trinkanti kasdienè veikla bei socialinè, psichologinè gerovè [6].

Ilgai trunkanti statine padètis yra pagrindinis veiksnys, sukeliantis nugaros ir pečiu juostos skausmus. Prie statinès padèties prisidedanti didelè akių ịtampa yra predisponuojantis veiksnys miofascijinių trigerinių taškų formavimuisi trapeciniame raumenyje [7]. Prie KRSS komplekso trigerinių taškų sukeltų kaklo ir nugaros skausmų prisideda pečių juostos, riešų skausmai, pirštų diskomfortas [8].

Ryški kompiuterio ekrano šviesa gali slopinti melatonino sekreciją ir atitolinti miego pradžią. Šviesa tarpininkauja žinduoliu paros ritmo sinchronizacijoje su aplinkos laiku, moduliuodama tinklainès ịvestị ị paros ritmo reguliatoriu - hipotalamo suprachiasmatinį branduoli [9]. Jame yra neuronai, turintys paros aktyvumo modelị ir reguliuojantys kankoréžinès liaukos hormono melatonino sekreciją, reaguodami i aplinkos šviesos-tamsos ciklą. Melatoninas - tai hormonas, išsiskiriantis silpnomis šviesos sąlygomis, kada būdraujame, bei dalyvaujantis fiziologinèje miego kontrolèje. Mèlyna šviesa taip pat gali pakeisti smegenų elektrini aktyvumą $[9,10]$.

Atsižvelgiant ị tai, kad miegas tarnauja gyvybiškai svarbiems fiziologiniams, pažintiniams ir psichologiniams procesams, miego kokybės atkūrimas yra būtinas tiek suaugusiems, tiek vaikams ir paaugliams [10]. Jis turi didelę ịtaką atminties konsolidavimui laipsniškai ịsisavinant epizodinius prisiminimus ị ilgalaikę atmintį. Miegas yra reikšmingas biologinis mechanizmas, reguliuojantis nuotaiką $[2,9,10]$. Studentai, kurių miegas sutrinka dèl technologijų naudojimo, gali būti labiau linkę patirti tokių depresijos požymių kaip energijos netekimas, dèmesio koncentracijos problemos ir mieguistumas dieną. Prastas miegas turi įtakos pažinimo ir mokymosi gebejjimams, o tai savo ruožtu blogina akademinę veiklą $[10,11]$.

Diagnostika. Diagnozuojant kompiuterinį regos sutrikimo sindromą, labai svarbu yra anamnezè ir klinikiniai duomenys. Rekomenduojama išsiaiškinti gretutinius akių nuovargị sukeliančius veiksnius: bendrą sveikatos būklę, vaistų vartojimą, aplinkos veiksnius. Naudinga įvertinti regos aštrumą, refrakciją, akių drauginius judesius ir gebejjimą sufokusuoti vaizdą [12]. Vienas iš pagrindinių šio sutrikimo simptomų yra akių sausumas. Jị nustatyti galima remiantis paciento skundais, akių vokų būkle, atliekant Širmerio testą, vertinant ašarų plèvelès suirimo laiką. Kartu gali būti nustatomas akies paviršiaus ligų indeksas (OSDI) [13].

Kompiuterio ekrane matomi vaizdai ir žodžiai sudaryti iš smulkių šviesos taškelių, vadinamų pikseliais. Šviesos intensyvumas juose žvelgiant iš krašto ị centrą stiprèja, todèl žmonėms sunku stebèti šiuos taškus ilgą laiką - tai sukelia akių nuovargio simptomus [12]. Teigiama, kad šis sindromas išsivysto naudojant kompiuterị $>3$ valandas per dieną arba $>30$ valandų per savaitę [13]. Nustatyta, kad prasidejjus COVID - 19 pandemijai, skaitmeninių prietaisų naudojimo laikas pailgejjo beveik 5 valandas, per dieną pasiekdamas apie 9 valandas [14]. Dèl šių pokyčių daugeja žmonių, nusiskundžiančių kompiuterinio regos sutrikimo sindromo simptomais: akių sausumu, nuovargiu, sudirginimu, neryškiu matymu, regos sutrikimais, galvos skausmais, miego sutrikimais, nugaros, pečiu juostos skausmais. Siejant klinikinius simptomus, akių ir regos pažeidimus su laiku, praleistu prie kompiuterio, galima ịtarti KRSS, nors dažnai ši liga lieka nediagnozuota $[4,13,14]$.

Gydymas ir profilaktika. Būklès progresavimas teigiama ar neigiama linkme labai priklauso nuo paciento motyvacijos ir ryžto keisti situaciją. Atlikti tyrimai rodo, kad žinios apie kompiuterinio regèjimo sutrikimą yra itin prastos, o apie savipagalbos ir profilaktikos būdus dažniausiai imama domètis tada, kai simptomai progresuoja ir tenka taikyti gydymą $[11,15]$.

Svarbiausias ir efektyviausias KRSS gydymas yra profilaktika. Nesaikingas kompiuterinių ịrenginių naudojimas, ypač naktị, mažina miego kiekị ir kokybę, didina nuovargị ir dèl to kenčia darbo kokybė [15]. Labiausiai efektyvus KRSS gydymo ir prevencijos metodas yra dažnos trumpos pertraukos. Jų metu rekomenduojama atlikti akių masažą, žiūrèti ị tolimus objektus, pabūti užsimerkus. Svarbu šalinti rizikos veiksnius - refrakterines ydas, akomodacijos, konvergencijos sutrikimus, akių sausumą. Tam naudojami korekciniai akiniai, akių geliai, lašai [16]. İrodyta, jog buvimas lauke, ypač miške, gerina regèjimą, padeda palaikyti emocinį stabilumą. Itin naudinga atlikti akių bei fizinę viso kūno mankštą [15]. Rekomenduojama ị kompiuterị žiūrèti žemyn $14^{0}$ kampu, kad akys būtu ties viršutiniu monitoriaus kraštu. Kompiuterio ekranas turètų būti nutolęs ištiestos rankos atstumu, apie 80 centimetrų nuo akių. Darbo vieta turi būti tvarkinga, kompiuterio ekranas reguliariai valomas, nustatomas atitinkamas apšvietimas, nesukeliantis atspindžio kompiuterio ekrane [16].

Trumpujų bangų pašalinimas naudojant atitinkamus blokuojamus akinius, keičiant kompiuterio ekrano nustatymus, naudojant programas, mažinančias mėlynos šviesos kiekị vakare gali pagerinti miego trukmę ir kokybę, sumažinti subjektyvų budrumą $[4,6,10,13,16]$.

Kineziterapija ir elektrosimuliacinès procedūros stiprina nugaros raumenis, tampa lengviau taisyklingai sèdèti ilgesni laiką. Masažas mažina raumenų įtampą, gerina emocinę būklę [15]. 


\section{Išvados}

1. Kompiuterinis regos sutrikimo sindromas - simptomy kompleksas, atsirandantis ilgą laiką leidžiant prie kompiuterio ekranų.

2. KRSS lemia regejjimo sutrikimą, miego sutrikimą, griaučių-raumenų sistemos patologiją.

3. KRSS - itin dažna problema, kuri dažnai nediagnozuojama.

4. Geriausia prevencija - ekranų naudojimo ribojimas iki būtinos veiklos bei žmonių švietimas.

\section{Literatūra}

1. Parihar JK, Jain VK, Chaturvedi P, Kaushik J, Jain G, Parihar AK. Computer and visual display terminals (VDT) vision syndrome (CVDTS). Med J Armed Forces India 2016;72:270-6.

https://doi.org/10.1016/j.mjafi.2016.03.016

2. Payne KB, Wharrad H, Watts K. Smartphone and medical related app use among medical students and junior doctors in the United Kingdom (UK): a regional survey. BMC Med Inform Decis Mak 2012;12:121.

https://doi.org/10.1186/1472-6947-12-121

3. Al Rashidi SH, Alhumaidan H. Computer vision syndrome prevalence, knowledge and associated factors among Saudi Arabia university students: is it a serious problem? Int J Health Sci (Qassim) 2017;11:17-9.

4. Gangamma MP, Poonam, Rajagopala M. A clinical study on "Computer vision syndrome" and its management with triphala eye drops and Saptamrita Lauha. Ayu 2010;31:236-9.

https://doi.org/10.4103/0974-8520.72407

5. Noreen K, Batool Z, Fatima T, Zamir T. Prevalence of computer vision syndrome and its associated risk factors among under graduate medical students. Pakistan Journal of Ophthalmology 2016;32(3):140-146.

6. Mork R, Helle K, Fostervold IK. Visual and psychological stress during computer work in healthy, young females - physiological responses. Int Arch Occup Environ Health 2018; 91(7):811-830. https://doi.org/10.1007/s00420-018-1324-5

7. Gowrisankaran S, Sheedy JE. Computer vision syndrome: a review. Work 2015;52(2):303-14. https://doi.org/10.3233/WOR-152162

8. Lurati AR. Computer vision syndrome: implications for the occupational health nurse. Workplace Health Saf 2018;66(2):56-60. https://doi.org/10.1177/2165079917731790

9. Stringham JM, Stringham NT, O'Brien KJ. Macular carotenoid supplementation improves visual performance, sleep quality, and adverse physical symptoms in those with high screen time exposure. Foods 2017;6(7):47. https://doi.org/10.3390/foods6070047

10. Hennies N, Lambon Ralph MA, Kempkes M, Cousins JN, Lewis PA. Sleep spindle density predicts the effect of prior knowledge on memory consolidation. J Neurosci 2016;36:3799-810.
https://doi.org/10.1523/JNEUROSCI.3162-15.2016

11. Ranasinghe P, Wathurapatha WS, Perera YS, Lamabadusuriya DA, Kulatunga S, Jayawardana N, Katulanda P. Computer vision syndrome among computer office workers in a developing country: an evaluation of prevalence and risk factors. BMC Res Notes 2016; 9:150.

https://doi.org/10.1186/s13104-016-1962-1

12. Randolph SA. Computer vision syndrome. Workplace Health Saf 2017;65(7):328.

https://doi.org/10.1177/2165079917712727

13. Sánchez-Valerio MDR, Mohamed-Noriega K, Zamora-Ginez I, Baez Duarte BG, Vallejo-Ruiz V. Dry eye disease association with computer exposure time among subjects with computer vision syndrome. Clin Ophthalmol 2020;14:4311-4317.

https://doi.org/10.2147/OPTH.S252889

14. Bahkir FA, Grandee SS. Impact of the COVID-19 lockdown on digital device-related ocular health. Indian J Ophthalmol 2020;68(11):2378-2383.

https://doi.org/10.4103/ijo.IJO_2306_20

15. Wolkoff, P. (2017). External eye symptoms in indoor environment. Indoor Air 2017;27:246-260.

https://doi.org/10.1111/ina.12322

16. Chawla A, Lim TC, Shikhare SN, Munk PL, Peh WCG. Computer vision syndrome: darkness under the shadow of light. Can Assoc Radiol J 2019;70(1):5-9.

https://doi.org/10.1016/j.carj.2018.10.005

\section{COMPUTER VISION SYNDROME - EPIDEMIOLOGY, DIAGNOSIS, TREATMENT, PREVENTION}

D. Mišeikytė, A. Judickaitė, S.R. Kužmarskytė

Keywords: computer vision syndrome, health education, occupational health and safety programs, eye strain, workstation design, eye examinations.

Summary

Computer vision syndrome (CVS) - is a complex of symptoms that are caused by an extended period aof screen time and computer use. It causes vision, eye, sleep disturbances accompanied by impairments in the musculoskeletal system. The diagnostics of this disease include evaluation of risk factors and clinical symptoms, the most prevalent ones are dry eyes, neck and shoulder pain. The evaluation of refraction, quality of eye movement, visual acuity, Schirmer's test, various questionnaires are beneficial when diagnosing CVS. The treatment consists of reducing the risk factors: correction of computer hygiene, adequate rest, exercise. For alleviating eye symptoms it is recommended to use eye gels, massages, electrostimulation to reduce the tension in muscles. Prevention is the most important way to avoid CVS, it includes appropriate usage of visual devices and proper rest times at work.

Correspondence to: do.miseikyte@gmail.com

Gauta 2021-02-22 